\title{
Morphological diversity of seeds of Polish Festulolium cultivars depending on weather conditions
}

\author{
B. BORAWSKA-JARMUŁOWICZ ${ }^{1 *}$, G. MASTALERCZUK ${ }^{1 *}$, E. MAŁUSZYŃSKA ${ }^{2}$, \\ and W. BORUCKI ${ }^{3}$
}

\author{
Institute of Agriculture, Warsaw University of Life Sciences, PL-02776, Warsaw, Poland 1 \\ The Plant Breeding and Acclimatization Institute - National Research Institute Radzików, PL-05870, Błonie, \\ Poland ${ }^{2}$ \\ Institute of Biology, Warsaw University of Life Sciences, PL-02776, Warsaw, Poland ${ }^{3}$
}

\begin{abstract}
Morphological traits of seeds of Festulolium braunii (K. Richt.) A. Camus cultivars were studied in relation to weather conditions. The obtained results show that morphological traits of seeds varied among cultivars and years of cultivation. The values of seed characteristics were higher in year 2016 due to more favorable weather conditions for plant growth. It was found that the husked seeds of Festulolium cultivars were characterized by a similar length and width regardless of the year, whereas naked seeds significantly differed in these characteristics. Mean values (from the research years) of seed parameters, such as thousand seed mass, area, convex area, shape factor, rectangle, as well as naked seed width showed variations among cultivars. At the same time, it was found that the mass of 1000 seeds of individual cultivars showed the smallest variability in both years of the study $(2.56-4.86 \%)$ indicating a high stability of this trait. Thousand seed mass was significantly correlated with husked seed length / husked seed width ratio and husked seed length, and weakly correlated with yield.
\end{abstract}

Additional key words: biometric parameters, husked and naked seeds, thousand seed mass.

\section{Introduction}

Festulolium braunii (K. Richt.) A. Camus plays an important role in agriculture. This is a relatively new species obtained by the crossing of meadow fescue (Festuca pratensis Huds.) with Italian ryegrass (Lolium multiflorum Lam.), combining feeding quality of ryegrass with the persistency and stress tolerance of fescue (Yamada et al. 2005, Ghesquière et al. 2010). European Commission extended the definition of Festulolium to all hybrids resulting from the crossing of a species of a genus Festuca with a species of a genus Lolium regardless the ploidy, chromosome number, and potential application of backcross during the cultivar development (Commission Directive 2004/55/EC). Consequently, Festulolium may at present include any amphiploid or introgression form derived from any Lolium $\times$ Festuca hybrid combination (Ghesquière et al. 2010). According to the EU Common catalogue of agricultural plant species, which is required for seed marketing over most countries in the world, 53 cultivars of Festulolium are registered (2019). Polish Festulolium cultivars (e.g. Agula, Felopa, Sulino) are all tetraploids $(2 \mathrm{n}=4 x=28)$ and have been bred using an amphiploidy approach. They derived mostly from reciprocal hybrids of $L$. multiflorum $\times F$. pratensis and $F$. pratensis $\times$ L. multiflorum. Present Festulolium cultivars are as much the result of breeding as that of antagonistic selective forces at genome and phenotype level. The first two Polish cultivars Felopa and Sulino were registered in 1998 and still are on the Polish National List of Agricultural Plants (2020). Recently, Festulolium cultivars are gaining increased interest as sources of reliable, productive, and nutritive fodder for livestock agriculture and for their potential ecosystem services (MacLeod et al. 2013, Humphreys et al. 2014).

Festulolium provide novel alternatives to existing grass cultivars that may either lack the fodder quality of Festulolium or their resilience against abiotic or

Submitted 16 June 2020, last revision 5 October 2020, accepted 6 October 2020.

Abbreviations: A - area of a particle; CA - convex area; CP - convex perimeter; D - diameter; ECD - equivalent circle diameter; F feret; HSL - husked seed length; HSW - husked seed width; MR - Martins radius; NSL - naked seed length; NSW - naked seed width; $\mathrm{P}$ - perimeter; R - rectangle; RL - rachilla length; SF - shape factor; TSM - thousand seed mass.

Acknowledgements: The authors would like to thank Eugeniusz Paszkowski from the Plant Breeding Station in Szelejewo, Poland, for the provision of seed material.

* Corresponding authors; e-mails: barbara_borawska_jarmulowicz@sggw.edu.pl,grazyna_mastalerczuk@sggw.edu.pl 
biotic stresses (Ghesquière et al. 2010). This species is known for its higher yield of green fodder and dry matter compared to parental species L. multiflorum and F. pratensis and improved fodder quality (Skládanka et al. 2010). Festulolium braunii is characterised by a higher seed yield potential, in some conditions comparable with L. multiflorum (Nekrošas and Kemešyte 2007). The characteristic feature of this crossbred is also improved tolerance to environmental stresses such as winter hardiness (Nekrošas and Kemešyte 2007, Šimkūnas et al. 2009, Abdelhalim et al. 2016) and tolerance to periodic droughts (Fariaszewska and Staniak 2015, Staniak and Harasim 2018, Perlikowski et al. 2019). This species can be also a valuable component in mixtures for temporary grassland, and can even be used for renovation of permanent meadows on mucky organic soil (Czyż et al. 2015).

As a fodder, Festulolium is characterized by good digestibility, favorable content of protein and soluble saccharides (Downing and Gamroth 2007, Czyż et al. 2015). Studies of Staniak and Harasim (2018) and Staniak (2019) showed that the effect of drought stress on the food value of Festulolium was smaller than on the yield. In the future, the interest of Festulolium will be certainly growing, due to its sustainable production during the expected climate change conditions. Moreover, this species is also useful for organic grass-seed production (Deleuran et al. 2010). In addition, there are appearing possibilities of using Festulolium for non-forage purposes such as amenity grass (Rzeźnik and Goliński 2013).

Due to the agriculturally favorable traits of Festulolium braunii, the demand for its sowing material increases (Ghesquière et al. 2010). Seed yield is always one of the key objective of research programs, because even topyield cultivars are not competitive on the seed market if their seed yield is poor (Nösberger and Staszewski 2002). Similar to other grass species, seeds yield of Festulolium differs among cultivars and it is dependent on the nitrogen fertilizer rate and climatic conditions (Gūtmane and Adamovičs 2005). In fodder cultivation, appropriate fertilization is necessary to obtain the highest possible yield of vegetative mass (Mastalerczuk et al. 2017a,b) whereas in seed crops, it should ensure even flowering of plants and seed maturation (Obraztsov et al. 2018a). Many experiments were carried out to determine reactions of Festulolium cultivars to soil structure, the amount of seeds sown, and the nitrogen fertilization (Hampton and Fairey 1997, Czyż and Kitczak 2015). In these experiments, there were estimated height of generative shoots, structure of inflorescences and spikelets, and seed set to select breeding material. Positive correlation between number of flowers and seed per spikelet was observed (Rzeźnik et al. 2014). Some studies also evaluated the methods to reduce shatter losses in the pre-harvesting period (Obraztsov et al. 2018b). In Festulolium braunii, rachilla of spikelets situated in the upper parts of the inflorescence tended to break with lower strength than those located in its lower parts (Rzeźnik et al. 2013). The examined genotypes were characterized regarding seed retention strength in spikelets, consequently by variability in susceptibility to kernel shedding. Research on the improvement of seed quality of this species has shown that the seed mass is a good indicator of their quality, there was a significant relationship between the seed germination capacity and the thousand seed mass (Orzeszko-Rywka et al. 2013). The results obtained by Smith et al. (2003) showed that the mass of an individual seed was a major determinant of all of the components of early vigor of Lolium perenne.

However, little information is available about biometric traits of Festulolium seeds and their influence on the mass of one thousand seeds. Hence, the aim of this study was to assess the morphological features of seeds of Festulolium cultivars in relation to weather conditions.

\section{Materials and methods}

Plants and growth conditions: The collection trials were carried out at the Plant Breeding Station in Szelejewo in Poland ( $51^{\circ} 54^{\prime} 00^{\prime \prime} \mathrm{N}, 17^{\circ} 12^{\prime} 00^{\prime \prime}$ E). Festulolium braunii (K. Richt. A. Camus) tetraploid Polish cultivars Agula, Felopa, and Sulino were sown on reproductive plantations on brown loam soil (IIIa valuation class). Annual plantations were established in 2015 and 2017 and seeds were sown in the $3^{\text {rd }}$ decade of August. The sowing rate was $2.0 \mathrm{~g} \mathrm{~m}^{-2}$ and row spacing of $25 \mathrm{~cm}$. Seeds characterized purity approx. $99 \%$ and germination rate $78-80 \%$. Plantations were established in accordance with the requirements for the production of certified seeds and for this species $200 \mathrm{~m}$ isolation from other cultivars was maintained to prevent pollination contamination.

Fertilizers were used in two terms $\left(\mathrm{g} \mathrm{m}^{-2}\right.$ in pure ingredient) - in autumn: N 0.9, P 1.32 and $\mathrm{K}$ 3.74; in spring: $\mathrm{N}$ (dose divided into 6.0 and 3.4), P 1.32 and $\mathrm{K}$ 3.74. Chemical plant protection was used in the spring during the tillering phase of plants (application of herbicide Chwastox Extra 300 SL - active ingredient 4-chloro-otolyloxyacetic acid at a dose of $0.3 \mathrm{~cm}^{3} \mathrm{~m}^{-2}$ ). The date of harvest depended on the maturity of the seeds and was carried out in the first decade of July in 2016 and 2018.

Seeds were collected in two stages: mowing and drying of the plants on swaths followed by threshing with a combine harvester. Average yields of seeds from reproductive plantations in 2016 were $100.03 \mathrm{~g} \mathrm{~m}^{-2}$ for Agula, $85.02 \mathrm{~g} \mathrm{~m}^{-2}$ for Felopa and $85.04 \mathrm{~g} \mathrm{~m}^{-2}$ for Sulino. In 2018, the seed yield of Agula was $90.05 \mathrm{~g} \mathrm{~m}^{-2}$, and of the other two cultivars $80.00 \mathrm{~g} \mathrm{~m}^{-2}$. After harvest, the cleaned seeds were cooled and dried to a moisture content below $14 \%$. Seed material of each Festulolium cultivar representing the reproductive years was collected in three lots of $500 \mathrm{~g}$.

Seed traits: Biometric research to examine the variability in morphological seed traits were carried out on randomly selected 50 seeds in two replicate samples per cultivar obtained from each year harvest (2016 and 2018). In the laboratory, seeds were measured individually using a digital microscope TAGARNO Trend (TAGARNO A/S, Horsens, Denmark). The following traits were assessed: 1) on seeds enclosed by the persistent husks (HS) - the 
length of seed (HSL), the width of seed (HSW) and the rachilla length (RL); 2) on naked seeds (NS) (after soaking the seeds and removing the husks) - seed length (NSL) and seed width (NSW).

Seed traits of husked seeds were also recorded using a binocular and digitized images of seeds applying microscopy Soft Imaging System (Münster, Germany).

The following traits were assessed:

- area $\left(\mathrm{A}, \mathrm{mm}^{2}\right)$ - the area of a particle is (number of pixels of the particle) times (calibration factors in $\mathrm{X}$ and Y direction);

- convex area $\left(\mathrm{CA}, \mathrm{mm}^{2}\right)$ - the area of the convex cover of the particle;

- equivalent circle diameter (ECD, mm) - the equivalence is referring to the area of the particle. The ECD is the diameter of a circle that has an area equal to the area of the particle, where a = area;

- diameter $(\mathrm{D}, \mathrm{mm})$ - the arithmetic mean of all diameters of particle (for angles $=1^{\circ}, 2^{\circ}, 3^{\circ}, \ldots .180^{\circ}$ );

- perimeter $(\mathrm{P})$ - the sum of the pixel distances along the closed boundary;

- convex perimeter (CP) - the perimeter of the convex cover of the particle;

- shape factor (SF) - the shape factor provides information about the "roundness" of the particle. For a spherical particle the shape factor is 1 , for all other particles it is smaller than 1. The formula for this calculation is: shape factor $=4 \pi \mathrm{a} / \mathrm{p}^{2}$, where $\mathrm{a}$ is area and $\mathrm{p}$ is perimeter;

- feret $(\mathrm{F}, \mathrm{mm})$ - the arithmetic mean distance of parallel tangents at opposing particle borders;

- Martins radius (MR, mm) - the mean separation of a particles center of gravity from its boundary points;

- rectangle $\left(\mathrm{R}, \mathrm{mm}^{2}\right)$ - the area of the arithmetic mean rectangle which sides consist of tangents to the particle borders.

The evaluation of the mass of 1000 seeds was performed in accordance with the ISTA rules (2019), i.e., 8 repetitions of 100 seeds per cultivar in each year of harvest (from collected lots).

Data analysis: All calculations were made using the Statistica v. 13.3 package (Statsoft, Tulsa, USA). As part of the empirical data analysis, variability of the examined features was calculated (mean, standard deviation, coefficient of variation). The experimental data were analyzed using 2-way ANOVA. Tukey's multiple range $F$ test was used to test for the effects of the treatments. Significant differences among the assessed traits of seeds were determined $(P \leq 0.05, P \leq 0.01)$. Multidimensional variation among the morphological traits of seeds and yield of Festulolium cultivars as well as weather conditions in years were summarized using principal component analysis (PCA).

Weather conditions: Meteorological conditions in individual years of research (obtained from Szelejewo Station) varied (Table 1 Suppl., Fig. 1 Suppl.). Precipitation in the period from September 2015 to June 2016 was approx. $467 \mathrm{~mm}$ and was $26 \%$ higher compared to the multi-year period (2001 - 2015). On the other hand, precipitation from September 2017 to June 2018 was approx. $340 \mathrm{~mm}$ and was less by about $8 \%$ compared to the multi-year period. The greatest amount of precipitation during the growing season from April to June was recorded in 2016 $(150.9 \mathrm{~mm})$. In relation to them, precipitation in 2018 accounted for approx. $50 \%$. This year, little precipitation also occurred in the winter (January - February, $45 \mathrm{~mm}$ ). Precipitation in the period April - May in 2016 was clearly greater $(103.6 \mathrm{~mm})$ than in $2018(40.6 \mathrm{~mm})$ and quite even (from 46 to $57 \mathrm{~mm}$ ). The thermal conditions during the growing season were similar (average $8.5^{\circ} \mathrm{C}$ ). However, there were differences in the number of frost days during the winter and early spring, in 2018 negative temperatures were for $55 \mathrm{~d}$, while in 2016 only for $36 \mathrm{~d}$.

\section{Results and discussion}

It was found that seeds with husks of Festulolium cultivars have similar length $(7.04-7.11 \mathrm{~mm})$ and width $(1.51-$ $1.54 \mathrm{~mm}$ ) regardless of the year of cultivation (Table 1). On the other hand, it was found that naked seeds of tested cultivars, independent of the year, significantly differed in these characteristics among cultivars and cv. Sulino had the lowest values. It was also shown that the length of naked seeds was $30 \%$ (Agula) to $33 \%$ (Sulino) shorter,

Table 1. Mean morphological seed traits of Festulolium cultivars in 2016 and 2018. Means with the same lower-case letters within columns are not significantly different at $P \leq 0.01$. * and ** - significant differences between treatments at $P \leq 0.05$ and 0.01 , respectively. HSL - husked seed length, HSW - husked seed width, RL - rachilla length, NSL - naked seed length, NSW - naked seed width, TSM thousand seed mass.

\begin{tabular}{llllllllll}
\hline Factors & & HSL $[\mathrm{mm}]$ & HSW [mm] & RL [mm] & NSL [mm] & NSW [mm] & HSL/HSW & NSL/NSW & TSM [g] \\
\hline Year (A) & 2016 & $7.28^{\mathrm{b}}$ & $1.55^{\mathrm{b}}$ & $1.64^{\mathrm{b}}$ & $4.94^{\mathrm{b}}$ & $1.51^{\mathrm{b}}$ & $4.75^{\mathrm{b}}$ & $3.32^{\mathrm{a}}$ & $3.93^{\mathrm{b}}$ \\
& 2018 & $6.88^{\mathrm{a}}$ & $1.51^{\mathrm{a}}$ & $1.53^{\mathrm{a}}$ & $4.75^{\mathrm{a}}$ & $1.42^{\mathrm{a}}$ & $4.60^{\mathrm{a}}$ & $3.38^{\mathrm{a}}$ & $3.48^{\mathrm{a}}$ \\
Cultivar (B) & Agula & $7.11^{\mathrm{a}}$ & $1.51^{\mathrm{a}}$ & $1.58^{\mathrm{ab}}$ & $4.96^{\mathrm{b}}$ & $1.44^{\mathrm{a}}$ & $4.73^{\mathrm{a}}$ & $3.47^{\mathrm{b}}$ & $3.78^{\mathrm{b}}$ \\
& Felopa & $7.04^{\mathrm{a}}$ & $1.53^{\mathrm{a}}$ & $1.53^{\mathrm{a}}$ & $4.85^{\mathrm{ab}}$ & $1.50^{\mathrm{b}}$ & $4.65^{\mathrm{a}}$ & $3.19^{\mathrm{a}}$ & $3.94^{\mathrm{c}}$ \\
& Sulino & $7.08^{\mathrm{a}}$ & $1.54^{\mathrm{a}}$ & $1.65^{\mathrm{b}}$ & $4.72^{\mathrm{a}}$ & $1.42^{\mathrm{a}}$ & $4.65^{\mathrm{a}}$ & $3.38^{\mathrm{ab}}$ & $3.40^{\mathrm{a}}$ \\
Year (A) & & $* *$ & $* *$ & $* *$ & $* *$ & $* *$ & $* *$ & $\mathrm{~ns}$ & $* *$ \\
Cultivar (B) & $\mathrm{ns}$ & $\mathrm{ns}$ & $* *$ & $* *$ & $* *$ & $\mathrm{~ns}$ & $* *$ & $* *$ \\
A $\times$ B & $* *$ & $* *$ & $* *$ & $*$ & $*$ & $*$ & $* *$ & $* *$ \\
\hline
\end{tabular}


Table 2. Interactions between the cultivar and year in morphological seed traits of Festulolium. Means with the same lower-case letters within columns and rows are not significantly different at $\mathrm{P} \geq 0.01 ; *$ and $* *$ represent significant differences between treatments at $P \leq 0.05$ and 0.01 , respectively. SE - standard error, CV - coefficient of variation; for explanation of other abbreviations see Table 1 .

\begin{tabular}{|c|c|c|c|c|c|c|c|c|c|}
\hline \multirow[t]{2}{*}{ Trait } & \multirow[t]{2}{*}{ Cultivar } & \multicolumn{4}{|l|}{2016} & \multicolumn{4}{|l|}{2018} \\
\hline & & Mean $\pm \mathrm{SE}$ & Min & Max & $\mathrm{CV}[\%]$ & Mean $\pm \mathrm{SE}$ & Min & Max & $\mathrm{CV}[\%]$ \\
\hline \multirow{3}{*}{$\begin{array}{l}\mathrm{HSL}^{* *} \\
{[\mathrm{~mm}]}\end{array}$} & Agula & $7.44 \pm 0.81^{\mathrm{c}}$ & 5.79 & 9.47 & 10.89 & $6.79 \pm 0.76^{\mathrm{a}}$ & 4.87 & 8.19 & 11.19 \\
\hline & Felopa & $7.30 \pm 0.90^{\mathrm{bc}}$ & 5.17 & 9.82 & 12.33 & $6.78 \pm 0.70^{\mathrm{a}}$ & 4.42 & 8.40 & 10.32 \\
\hline & Sulino & $7.10 \pm 0.71^{\mathrm{b}}$ & 5.57 & 9.30 & 10 & $7.06 \pm 0.75^{\mathrm{ab}}$ & 5.13 & 8.68 & 10.62 \\
\hline \multirow{3}{*}{$\begin{array}{l}\mathrm{HSW}^{* *} \\
{[\mathrm{~mm}]}\end{array}$} & Agula & $1.56 \pm 0.24^{b}$ & 1.17 & 1.56 & 15.38 & $1.46 \pm 0.18^{\mathrm{a}}$ & 0.99 & 1.91 & 12.33 \\
\hline & Felopa & $1.55 \pm 0.23^{b}$ & 1.03 & 2.20 & 14.85 & $1.51 \pm 0.18^{\mathrm{ab}}$ & 1.07 & 2.11 & 11.92 \\
\hline & Sulino & $1.52 \pm 0.17^{\mathrm{ab}}$ & 1.13 & 1.94 & 11.18 & $1.55 \pm 0.18^{\mathrm{b}}$ & 1.07 & 1.91 & 11.61 \\
\hline \multirow{3}{*}{$\begin{array}{l}\mathrm{RL}^{* *} \\
{[\mathrm{~mm}]}\end{array}$} & Agula & $1.70 \pm 0.29^{c}$ & 0.94 & 1.70 & 17.06 & $1.46 \pm 0.27^{\mathrm{a}}$ & 0.95 & 2.52 & 18.49 \\
\hline & Felopa & $1.56 \pm 0.29^{\mathrm{ab}}$ & 0.95 & 2.36 & 18.59 & $1.49 \pm 0.29^{\mathrm{a}}$ & 0.79 & 2.44 & 19.57 \\
\hline & Sulino & $1.65 \pm 0.32^{\mathrm{bc}}$ & 0.94 & 2.69 & 19.54 & $1.64 \pm 0.33^{\mathrm{bc}}$ & 1.02 & 2.61 & 19.46 \\
\hline \multirow{3}{*}{$\begin{array}{l}\text { NSL* } \\
{[\mathrm{mm}]}\end{array}$} & Agula & $4.80 \pm 0.46^{\mathrm{bc}}$ & 3.92 & 5.76 & 9.58 & $5.12 \pm 0.59^{\mathrm{d}}$ & 3.79 & 6.03 & 11.52 \\
\hline & Felopa & $5.05 \pm 0.55^{\text {cd }}$ & 3.68 & 6.19 & 10.89 & $4.65 \pm 0.49^{\mathrm{ab}}$ & 3.25 & 5.70 & 10.54 \\
\hline & Sulino & $4.96 \pm 0.67^{\mathrm{bcd}}$ & 3.10 & 6.18 & 13.51 & $4.47 \pm 0.51^{\mathrm{a}}$ & 3.14 & 5.71 & 11.41 \\
\hline \multirow{3}{*}{$\begin{array}{l}\mathrm{NSW}^{*} \\
{[\mathrm{~mm}]}\end{array}$} & Agula & $1.44 \pm 0.14^{\mathrm{a}}$ & 1.14 & 1.70 & 9.72 & $1.44 \pm 0.16^{\mathrm{a}}$ & 0.96 & 1.66 & 11.11 \\
\hline & Felopa & $1.63 \pm 0.16^{\mathrm{b}}$ & 1.06 & 1.97 & 9.82 & $1.44 \pm 0.15^{\mathrm{a}}$ & 1.19 & 1.74 & 10.42 \\
\hline & Sulino & $1.45 \pm 0.20^{\mathrm{a}}$ & 1.01 & 1.82 & 13.79 & $1.38 \pm 0.21^{\mathrm{a}}$ & 0.92 & 1.83 & 15.22 \\
\hline \multirow[t]{3}{*}{ HSL/HSW* } & Agula & $4.78 \pm 0.49^{b}$ & 3.75 & 6.64 & 10.25 & $4.68 \pm 0.55^{\mathrm{ab}}$ & 3.53 & 6.18 & 11.75 \\
\hline & Felopa & $4.77 \pm 0.61^{\mathrm{b}}$ & 3.13 & 6.64 & 12.79 & $4.54 \pm 0.53^{\mathrm{a}}$ & 3.09 & 6.26 & 11.67 \\
\hline & Sulino & $4.70 \pm 0.55^{\mathrm{ab}}$ & 3.17 & 5.95 & 11.62 & $4.59 \pm 0.54^{\mathrm{ab}}$ & 3.61 & 6.43 & 11.76 \\
\hline \multirow{3}{*}{$\mathrm{NSL} / \mathrm{NSW}^{* *}$} & Agula & $3.36 \pm 0.31^{\mathrm{abc}}$ & 2.70 & 4.12 & 9.23 & $3.58 \pm 0.38^{c}$ & 2.66 & 4.07 & 10.61 \\
\hline & Felopa & $3.12 \pm 0.46^{\mathrm{c}}$ & 2.37 & 4.84 & 14.74 & $3.26 \pm 0.45^{\mathrm{ab}}$ & 2.22 & 4.52 & 13.8 \\
\hline & Sulino & $3.48 \pm 0.67^{\mathrm{bc}}$ & 2.44 & 5.78 & 19.25 & $3.28 \pm 0.49^{\mathrm{a}}$ & 2.07 & 4.62 & 14.94 \\
\hline \multirow{3}{*}{$\begin{array}{l}\text { TSM }^{* *} \\
{[\mathrm{~g}]}\end{array}$} & Agula & $3.91 \pm 0.19^{c}$ & 3.62 & 4.17 & 4.86 & $3.65 \pm 0.14^{\mathrm{b}}$ & 3.42 & 3.86 & 3.84 \\
\hline & Felopa & $4.62 \pm 0.14^{\mathrm{e}}$ & 4.17 & 4.62 & 3.03 & $3.51 \pm 0.09^{\mathrm{ab}}$ & 3.34 & 3.60 & 2.56 \\
\hline & Sulino & $3.92 \pm 0.18^{\mathrm{ab}}$ & 3.35 & 3.92 & 4.59 & $3.28 \pm 0.09^{\mathrm{a}}$ & 3.13 & 3.38 & 2.74 \\
\hline
\end{tabular}

while the width was smaller by only $2 \%$ (Felopa) to $8 \%$ (Sulino) compared to husked seeds. Cv. Felopa had the largest mass of a thousand seeds, while cv. Sulino the smallest. According to Orzeszko-Rywka et al. (2013), Festulolium seed mass is a good indicator of the quality of seeds and there is a high positive correlation between germination capacity and thousand seed mass. The authors also reported that a significant improvement in the seed quality of this species can be achieved by fractionating the seed lot to discard about $15-20 \%$ of the seeds with the lowest mass. Smith et al. (2003) also stated that high seed mass has a large impact on the early vigor of seedlings of Lolium perenne cultivars, which suggests that similar regularity may occur in Festulolium.

There were also significant differences between the years. The values of all seed characteristics were higher in 2016, presumably due to weather conditions more favorable for plant growth. In 2016, the cultivars generally developed seeds of higher mass. This is in line with results of Czyż and Kitczak (2015) who also indicate a clear impact of weather conditions on Festulolium seed yield. The authors obtained the highest yield of Festulolium seeds in the year, which was distinguished by the large amount of precipitation.
On average, husked seed length ranged from 6.78 to $7.44 \mathrm{~mm}$ among all cultivars and years (CV 10.00 - $12.33 \%$ ), while mean seed width varied from 1.46 to $1.56 \mathrm{~mm}$ (CV reached even 15.38\% in 2016) (Table 2). Mean rachilla length was higher in 2016 (1.70, on average) and showed higher variability than previous seed characteristics (17.06 - $19.57 \%)$. In contrast, less variation was found for the characteristics of seeds after removal of husks, especially for the Agula and Felopa (9.58 - $11.52 \%)$. It was also found that the mass of one thousand seeds of individual cultivar showed the smallest differentiation in both years of the study $(2.56-4.86 \%)$. Small values of the coefficient of variation of the thousand seeds mass of all cultivars indicate high TSM stability (in years and repetitions) as compared to the clearly higher values of this coefficient in relation to the other analyzed seed traits (CV from 9.23 to $19.57 \%$ ). This correlates with the results of Volterrani et al. (1999) and Goliński and Walerowska (2007), who also noted low CV values for TSM.

Also the morphological traits of seeds varied among Festulolium cultivars (Table 3). Cultivar Agula was characterized by the lowest values of all evaluated seed characteristics (except SF), while Felopa had similar or 
Table 3. Seed traits of Festulolium depending on cultivar and year of determination. Means with the same lower-case letters within each trait in columns and rows are not significantly different at $P \geq 0.01$. A - area of a particle, CA - convex area, ECD - equivalent circle diameter, D - diameter, P - perimeter, CP - convex perimeter, SF - shape factor, F - feret, MR - Martins radius, R - rectangle.

\begin{tabular}{|c|c|c|c|c|c|c|c|c|c|c|c|}
\hline Year & Cultivar & $\mathrm{A}\left[\mathrm{mm}^{2}\right]$ & $\mathrm{CA}\left[\mathrm{mm}^{2}\right]$ & $\mathrm{ECD}[\mathrm{mm}]$ & $\mathrm{D}[\mathrm{mm}]$ & $\mathrm{P}[\mathrm{mm}]$ & $\mathrm{CP}[\mathrm{mm}]$ & SF & $\mathrm{F}[\mathrm{mm}]$ & $\mathrm{MR}[\mathrm{mm}]$ & $\mathrm{R}\left[\mathrm{mm}^{2}\right]$ \\
\hline 2016 & & $9.98^{\mathrm{b}}$ & $11.17^{\mathrm{b}}$ & $3.55^{\mathrm{b}}$ & $7.36^{\mathrm{b}}$ & $17.98^{\mathrm{b}}$ & $17.93^{\mathrm{b}}$ & $0.40^{\mathrm{a}}$ & $5.57^{\mathrm{b}}$ & $1.49^{\mathrm{b}}$ & $27.33^{\mathrm{b}}$ \\
\hline \multirow[t]{4}{*}{2018} & & $9.03^{\mathrm{a}}$ & $9.81^{\mathrm{a}}$ & $3.37^{\mathrm{a}}$ & $6.58^{\mathrm{a}}$ & $16.16^{\mathrm{a}}$ & $16.16^{\mathrm{a}}$ & $0.44^{\mathrm{b}}$ & $5.03^{\mathrm{a}}$ & $1.42^{\mathrm{a}}$ & $22.45^{\mathrm{a}}$ \\
\hline & Agula & $9.07^{\mathrm{a}}$ & $9.81^{\mathrm{a}}$ & $3.38^{\mathrm{a}}$ & $6.73^{\mathrm{a}}$ & $16.34^{\mathrm{a}}$ & $16.45^{\mathrm{a}}$ & $0.43^{\mathrm{b}}$ & $5.11^{\mathrm{a}}$ & $1.42^{\mathrm{a}}$ & $23.18^{\mathrm{a}}$ \\
\hline & Felopa & $10.16^{\mathrm{b}}$ & $11.12^{\mathrm{b}}$ & $3.58^{\mathrm{b}}$ & $7.00^{\mathrm{ab}}$ & $17.20^{\mathrm{b}}$ & $17.21^{\mathrm{b}}$ & $0.44^{\mathrm{b}}$ & $5.36^{\mathrm{b}}$ & $1.52^{\mathrm{b}}$ & $25.52^{\mathrm{b}}$ \\
\hline & Sulino & $9.28^{\mathrm{a}}$ & $10.54^{\mathrm{b}}$ & $3.42^{\mathrm{a}}$ & $7.18^{\mathrm{b}}$ & $17.68^{\mathrm{b}}$ & $17.47^{\mathrm{b}}$ & $0.39^{\mathrm{a}}$ & $5.42^{\mathrm{b}}$ & $1.44^{\mathrm{a}}$ & $25.96^{\mathrm{b}}$ \\
\hline \multirow[t]{3}{*}{2016} & Agula & $10.08^{\mathrm{c}}$ & $10.96^{\mathrm{c}}$ & $3.57^{\mathrm{c}}$ & $7.29^{\mathrm{cd}}$ & $17.48^{\mathrm{b}}$ & $17.75^{\mathrm{cd}}$ & $0.42^{\mathrm{b}}$ & $5.51^{\mathrm{cd}}$ & $1.49^{\mathrm{bc}}$ & $26.62^{\mathrm{bcd}}$ \\
\hline & Felopa & $10.34^{\mathrm{c}}$ & $11.36^{\mathrm{c}}$ & $3.61^{\mathrm{c}}$ & $7.20^{\mathrm{bcd}}$ & $17.60^{\mathrm{b}}$ & $17.63^{\mathrm{bcd}}$ & $0.43^{\mathrm{b}}$ & $5.49^{\mathrm{bcd}}$ & $1.53^{\mathrm{c}}$ & $26.70^{\mathrm{cd}}$ \\
\hline & Sulino & $9.53^{\mathrm{bc}}$ & $11.20^{\mathrm{c}}$ & $3.47^{\mathrm{bc}}$ & $7.60^{\mathrm{d}}$ & $18.88^{\mathrm{c}}$ & $18.41^{\mathrm{d}}$ & $0.36^{\mathrm{a}}$ & $5.71^{\mathrm{d}}$ & $1.45^{\mathrm{bc}}$ & $28.65^{\mathrm{d}}$ \\
\hline \multirow[t]{3}{*}{2018} & Agula & $8.07^{\mathrm{a}}$ & $8.67^{\mathrm{a}}$ & $3.19^{\mathrm{a}}$ & $6.17^{\mathrm{a}}$ & $15.20^{\mathrm{a}}$ & $15.15^{\mathrm{a}}$ & $0.44^{\mathrm{b}}$ & $4.72^{\mathrm{a}}$ & $1.34^{\mathrm{a}}$ & $19.74^{\mathrm{a}}$ \\
\hline & Felopa & $9.99^{c}$ & $10.88^{\mathrm{bc}}$ & $3.55^{\mathrm{c}}$ & $6.81^{\mathrm{bc}}$ & $16.81^{\mathrm{b}}$ & $16.79^{\mathrm{bc}}$ & $0.45^{\mathrm{b}}$ & $5.23^{\mathrm{bc}}$ & $1.51^{\mathrm{c}}$ & $24.34^{\mathrm{bc}}$ \\
\hline & Sulino & $9.02^{\mathrm{b}}$ & $9.88^{\mathrm{b}}$ & $3.37^{\mathrm{b}}$ & $6.75^{\mathrm{b}}$ & $16.47^{\mathrm{b}}$ & $16.53^{b}$ & $0.43^{\mathrm{b}}$ & $5.14^{\mathrm{b}}$ & $1.42^{\mathrm{b}}$ & $23.28^{\mathrm{b}}$ \\
\hline
\end{tabular}

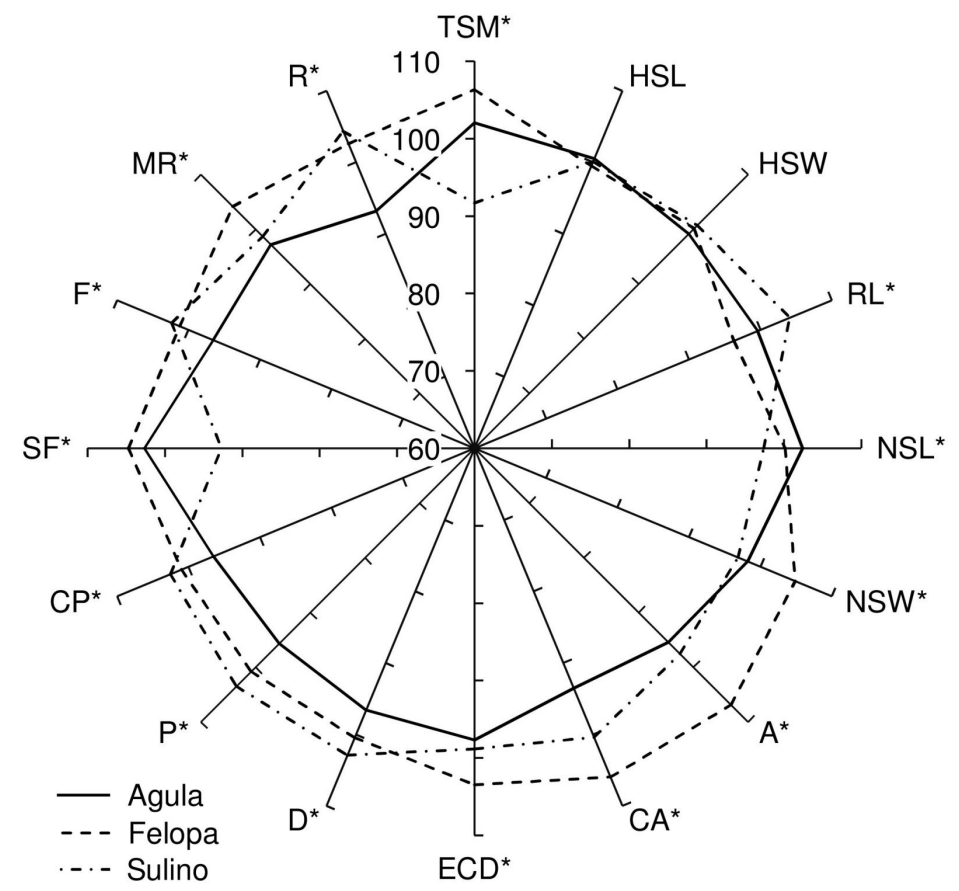

Fig. 1. The deviation of seed traits of Festulolium cultivars (Agula, Felopa, Sulino). Means from the years of determination (2016 and 2018) demonstrated on a radar plot. Values of each trait were treated in scale - the mean value is $100 \%$. * - significant differences between traits at $P \leq 0.01$.

significantly higher values (e.g. A, ECD, SF, MR) of these parameters compared to Sulino cultivar. It was found that Felopa formed seeds with the area $10.16 \mathrm{~mm}^{2}$ while the other two cultivars between 9.07 and $9.28 \mathrm{~mm}^{2}$. It was also found that in 2016, the differences in the values of almost all individual traits between cultivars were not significant. Only Sulino had a significantly higher perimeter $(\mathrm{P})$ and significantly lower shape factor (SF) values compared to others. On the other hand, variability among cultivars in most of the traits was significant in 2018, when rainfall was small. Cultivars Felopa and Sulino were characterized by significantly higher values of seed parameters compared to Agula, which may indicate higher drought tolerance by the former two cultivars compared to Agula.

Our study revealed that cultivars differed significantly only in TSM (Fig. 1). At the same time, no differences were found among the cultivars in the case of HSL and HSW. The other traits showed a variability among cultivars, but it was not always significant for all cultivars. Similarly, variability in seed morphological characteristics among different cultivars were observed in Dactylis glomerata (Borawska-Jarmułowicz 2018).

Variation has been tested by PCA (principal component analysis). The first component PC1 explains $56.88 \%$ of the variation, while the second component PC2 accounts for $16.28 \%$ (Fig. 2 Suppl.). Growth conditions and cultivar 
(combination) most strongly affected F, R, D, and P. It was found that A, CA, ECD, MR, and HSW also depended on these factors to a significant, but slightly smaller extent. TSM was most strongly correlated with HSL/HSW ratio and HSL, while weaker correlation was observed with yield. At the same time, it was shown that these features reached the highest values in all tested cultivars in 2016 (year with favorable weather conditions). Significant relationships between seed traits and the thousand seed mass in conditions of higher rainfall and moderate temperatures during the period from the April to the time of seed collection was also reported in Dactylis glomerata (Borawska-Jarmułowicz 2018).

The results of this study indicate that the length of the husked seeds and the ratio of the length of the husked seeds to their width correlates well with the thousand seeds mass. At the same time, the relationship between yield and thousand seeds mass was less clear. These characteristics are also most closely related to the weather conditions for all Festulolium cultivars evaluated. Relatively high and evenly distributed rainfall has a positive effect on the values of these parameters. It was also found that the mass of one thousand seeds of individual cultivar is a stable feature characterized by the lowest variation.

\section{References}

Abdelhalim, M., Rognli, O.A., Hofgaard, I.S., Østrem, L. Tronsmo, A.M.: Snow mould resistance under controlled conditions and winter survival in the field in populations of perennial ryegrass, meadow fescue and Festulolium are partly dependent on ploidy level and degree of northern adaptation. - Can. J. Plant Sci. 96: 579-589, 2016.

Borawska-Jarmułowicz, B.: Relationships between different morphological traits of panicles and seeds of Dactylis glomerata L. varieties under seed utilization. - Agr. Food Sci. 27: 179-189, 2018.

Czyż, H., Kitczak, T.: The response of Festulolium braunii (K. Richter) A. Camus to the amount of seeds sown and the level of nitrogen fertilisation in cultivation for seeds. - Folia Pomer. Univ. Technol. Stetin 316: 33-40, 2015.

Czyż, H., Jänicke, H., Kitczak, T., Bury, M.: The usefulness of grass mixtures with Festulolium braunii and Lolium perenne for the renewal of grasslands on mucky organic soil. - Woda Środowisko Obszary Wiejskie 50: 17-29, 2015.

Deleuran, L.C., Grislum, R., Boelt, B.: Effect of seed rate and row spacing in seed production of Festulolium. - Acta agr. scand. 60: 152-156, 2010 .

Downing, T., Gamroth, M.: Nonstructural carbohydrates in cool-season grasses. - Oregon State Univ. Extension Service. Special Rep. 1079-E. 11: 1-6, 2007.

Fariaszewska, A., Staniak, M.: Changes in yield, leaf area and fluorescence chlorophyll parameters of different forage grasses cultivars under drought stress. - Acta Sci. Pol. Agr. 14: 27-38, 2015.

Ghesquiere, M., Humphreys, M.W., Zwierzykowski, Z.: Festulolium. - In: Boller, B., Posselt, U.K., Veronesi, F. (ed.): Fodder Crops and Amenity Grasses. Pp. 293-315. Springer, New York - Dordrecht - Heidelberg - London 2010.

Goliński, P., Walerowska, M.: Variation of selected biological features and the seed potential of Poa pratensis (Poaceae). Frag. Flor. Geobot. Pol. 9 (Suppl.): 147-154, 2007.
Gūtmane, I., Adamovičs, A.: Use of Festulolium and Lolium x boucheanum for forage and seed production. - Grassl. Sci. Eur. 10: 503-506, 2005.

Hampton, J.G., Fairey, D.T.: Components of seed yields in grasses and legumes. - In: Fairey, D.T., Hampton, J.G. (ed.): Forage Seed Production. Temperate Species. Vol. 1. Pp. 4569. CABI, Walingford 1997.

Humphreys, M.W., O’Donovan, S.A., Farrell, M.S., Gay, A.P., Kingston-Smith, A.H.: The potential of novel Festulolium (2n $=4 x=28$ ) hybrids as productive, nutrient-use-efficient fodder for ruminants. - Food Energy Security 3: 98-110, 2014.

MacLeod, C.J.A., Humphreys, M.W., Whalley, R., Turner, L.B., Binley, A., Watts, C.W., Skøt, L., Joynes, A., Hawkins, S., King, I.P., O'Donovan, S., Haygarth, P.M.: A novel grass hybrid to reduce flood generation in temperate regions. - Sci. Rep. 3: 1-7, 2013.

Mastalerczuk, G., Borawska-Jarmułowicz, B., Kalaji, H.M., Dąbrowski, P., Gozdowski, D.: Some physiological parameters, biomass distribution and carbon allocation in roots of forage grasses growing under different nitrogen dosages. - Chiang Mai J. Sci. 44: 1295-1303, 2017 a.

Mastalerczuk, G., Borawska-Jarmułowicz, B., Kalaji, H.M., Dąbrowski, P., Paderewski, J.: Gas-exchange parameters and morphological features of festulolium (Festulolium braunii K. Richert A. Camus) in response to nitrogen dosage. Photosynthetica 55: 20-30, 2017 b.

Nekrošas, S., Kamešyte, V.: Breeding of ryegrass and Festulolium in Lithuania. - Žemdirbyste Agr. 94: 29-39, 2007.

Nösberger, J., Staszewski, Z.: Overview of the changes in research on grasslands in Europe. - Grassl. Sci. Eur. 7: 17-27, 2002.

Obraztsov, V., Shchedrina, D., Kadyrov, S.: Festulolium seed production dependence on fertilizer application system. Agron. Res. 16: 846-853, 2018 a.

Obraztsov, V., Shchedrina, D., Kadyrov, S.: Film agents as an effective means of reducing seed shattering in Festulolium. Agron. Res. 16: 2130-2136, 2018 b.

Orzeszko-Rywka, A., Rochalska, M., Podlaski, S., Grzywacz, P.: Seed separation as ecological method of seed quality improvement of festulolium (Festulolium braunii). - J. Res. appl. Agr. Engn. 58: 86-90, 2013.

Perlikowski, D.B., Augustyniak, A., Masajada, K.K., Skirycz, A., Soja, A.M., Michaelis, A., Wolter, G., Kosmala, A.: Structural and metabolic alterations in root systems under limited water conditions in forage grasses of Lolium-Festuca complex. Plant Sci. 283: 211-223, 2019.

Rzeźnik, A., Golińska, B., Goliński, P.: Differentiation of breeding materials of Festulolium braunii in regard to selected morphological-biological properties determined seed yield. Grassl. Sci. Poland 17: 105-115, 2014.

Rzeźnik A., Golińska, B., Goliński, P.: Investigations on tensile strength of rachilla and seed retention strength in spikelets of Festulolium braunii. - Grassl. Sci. Poland 16: 69-78, 2013.

Rzeźnik, A., Goliński, P.: Breeding achievement of $\times$ Festulolium hybrids. - Grassl. Sci. Poland 16: 79-98, 2013.

Šimkūnas, A., Valašinate, S., Mažeika, V.: Peculiarities of various Festulolium braunii cultivars development and overwintering. - LŽŪU Mokslo Darbai 85: 35-38, 2009.

Skládanka, J., Adam, V., Ryant, P., Doležal, P., Havlíček, Z.: Can Festulolium, Dactylis glomerata and Arrhenatherum elatius be used for extension of the autumn grazing season in Central Europe? - Plant Soil Environ. 56: 488-498, 2010.

Smith, K.F., McFarlane, N.M., Croft, V.M., Trigg, P.J., Kearney, G.A.: The effects of ploidy and seed mass on the emergence and early vigor of perennial ryegrass (Lolium perenne L.) cultivars. - Aust. J. exp. Agr. 43: 481-486, 2003. 
Staniak, M.: Changes in yield and nutritive value of red clover (Trifolium pratense L.) and festulolium (Festulolium braunii (K. Richt) A. Camus) under drought stress. - Agr. Food Sci. 28: 27-34, 2019.

Staniak, M., Harasim, E.: Changes in nutritive value of alfalfa (Medicago (varia T. Martyn) and festulolium (Festulolium braunii (K. Richt) A. Camus) under drought stress. - J. Agron. Crop Sci. 204: 456-466, 2018.

Volterrani, M., Bardini, G., Magnis, S., Bonami, E.: Comparative study turfgrass cultivars of Festuca arudinacea Schreb, Lolium perenne $\mathrm{L}$ and Poa partensis $\mathrm{L}$ in the coastal environment of Tuscany. - In: Falcinelli, M., Rosellini, D. (ed.): Herbage seed as a key factor for improving production and the environmental quality. Proceedings of the $4^{\text {th }}$ International Herbage Seed Conference. Pp. 309-313. University of Perugia, Perugia 1999.

Yamada, T.J., Forster, W., Humphreys, M.W., Takamizo, T.: Genetics and molecular breeding in Lolium/Festuca grass species complex. - Grass. Sci. 51: 89-106, 2005. 